\title{
Effects of Various Stimuli on Plasma Dopamine $\beta$-Hydroxylase Activity in Essential Hyperten- sion with Respect to Aging and Hyper- tension Severity Index
}

\author{
Fumiko Iseki, M.D., Masato Kuchi, M.D., Yasumasa Miyamoto, M.D., \\ Toshiaki Tamaki, M.D., Ichiro Nishio, M.D,, \\ and Yoshiaki Masuyama, M.D.
}

\section{SUMmary}

Effects of various stimuli on plasma dopamine $\beta$-hydroxylase (DBH) activity were studied in the patients with essential hypertension in relation to the age and the hypertension severity. Twenty minutes-standing, treadmill exercise, low sodium diet for 3 days and 2 hours-standing were used as the sympathetic stimuli.

The increase in plasma DBH activity by 20 minutes-standing and by treadmill exercise was small, and no significant difference was found in relation to the age and the hypertension severity index.

While, by low sodium diet for 3 days, the increase in plasma $\mathrm{DBH}$ activity was significantly higher in the hypertensives aged 20-39 than in those aged $40-59(\mathrm{p}<0.01)$ and above $60(\mathrm{p}<0.05)$.

The increase in plasma DBH activity by the stimulus was also significantly higher in the mild hypertensives than in the moderate $(p<0.05)$ and the severe hypertensives $(p<0.01)$.

By low sodium diet and 2 hours-standing, the increase in plasma DBH activity was significantly higher in the hypertensives aged 20-39 than in those aged $40-59(p<0.05)$. The increase in plasma DBH activity by the stimuli was also significantly higher in the mild hypertensives than in the moderate hypertensives $(\mathrm{p}<0.0 \mathrm{I})$. The increase in plasma $\mathrm{DBH}$ activity in the high renin group was significantly higher than that in the low renin hypertensives $(\mathrm{p}<0.05)$, though there was no significant difference in the basal plasma DBH activity. The increase in plasma $\mathrm{DBH}$ activity in the hypertensives with a fall of mean blood pressure of more than 10 $\mathrm{mmHg}$ by low sodium diet for 3 days was significantly higher than in those without significant blood pressure fall $(p<0.05)$.

Plasma DBH activity was more markedly increased by treadmill exercise in the hypertensives with positive EGG responses than in the

From the Division of Cardiology, Department of Medicine, Wakayama Medical College (Professor: Yoshiaki Masuyama, M.D.), Wakayama.

Address for reprints: Fumiko Iseki, M.D., Division of Cardiology, Department of Medicine, Wakayama Medical College, 1, 7-Bancho, Wakayama 640, Japan.

Received for publication September 21, 1978.

Manuscript revised January 24, 1979. 
normotensives with negative EGG responses to exercise $(p<0.05)$.

Significant correlation was found between plasma DBH activity and serum catecholamine in the mild and the moderate hypertensives $(p<$ $0.05)$.

These results suggest that the sympathetic nerve activity might play a role in the pathogenesis of hypertension in the early stage of essential hypertension and measurement of the responses of plasma DBH activity to low sodium diet for 3 days is one of the valuable indicators of the sympathetic nerve activity in the hypertensive patients.

\section{Additional Indexing Words :}

Sympathetic nerve activity Standing Treadmill exercise Low sodium diet

I T has been suggested that the sympathetic nerve system plays an important role in the pathogenesis of hypertension. Recently, plasma dopamine $\beta$ hydroxylase (DBH) activity and catecholamine levels have been measured as the index of sympathetic nerve activity in essential hypertension. Our previous results showed that plasma DBH activity was gradually decreased with age and the activity was higher in the hypertensives than in the normotensives in all age groups and significantly higher in the group of 45-64 years. ${ }^{11}$ It was significantly lower in the moderate and severe hypertensives than in the mild hypertensives. ${ }^{2}$ ) Therefore, the age-related change and the hypertension severity should be considered for evaluating plasma DBH activity.

As basal plasma DBH activity shows individual variation, the responses of plasma DBH activity to various stimuli would be more suitable as an indicator of the sympathetic nerve activity.

However, little is known about the effects of aging and hypertension severity on the responses of plasma DBH activity in essential hypertension.

The present study was attempted to compare the responses of plasma $\mathrm{DBH}$ activity to 20 minutes-standing, treadmill exercise, low sodium diet for 3 days and 2 hours-standing in relation to the age and the hypertension severity in essential hypertension and to evaluate the role of sympathetic nerve activity in essential hypertension.

\section{Materials and Methods}

The effect of 20 minutes-standing on plasma DBH activity was tested in 55 patients with essential hypertension and the effect of treadmill exercise was studied in 40 normotensives and 34 patients with essential hypertension. The response to low sodium diet for 3 days was tested in 34 patients with essential hypertension and the responses to low sodium dict for 3 days and 2 hours-standing were also observed 
in 29 patients with essential hypertension.

The hypertension severity index was determined by the criteria of the Hypertension Research Committee of Tokyo University. ${ }^{3}$ )

The blood samples were obtained in the outpatients after 30 minutes-bed rest and after standing for $20 \mathrm{~min}$. The blood samples were obtained before and immediately after treadmill exercise test. In the hospitalized patients, the blood samples were obtained before and after low sodium diet for 3 days and also after 2 hours-standing. The treadmill exercise test was performed according to the criteria by Kattus." The following criteria were used as the indicators to stop the loading, 1) heart rate exceeded $85 \%$ of the age-matched maximal heart rate proposed by Robinson, ${ }^{5)}$ 2) anginal pain was complained, 3) the subjects became strongly tired, 4) the positive ST depression was found and remarkable arrhythmias were observed. The followings were used as the positive criteria: 1) ST depression more than $1 \mathrm{~mm}$ with horizontal or falling ST segments, 2) ST depression more than $2 \mathrm{~mm}$ at $0.06 \mathrm{sec}$ from the ST junction with rising ST segment, or 3 ) the appearance of remarkably frequent extrasystoles or A-V block.

Plasma DBH activity was measured by the photometric method described by Nagatsu and Udenfriend ${ }^{6}$ and expressed in international units. Serum catecholamine was measured by the radiometric enzymatic method by de Champlain et $\mathrm{al}^{7}$ ) and expressed in $\mathrm{ng} / \mathrm{ml}$ and plasma renin activity was expressed in $\mathrm{ng} / \mathrm{ml} / \mathrm{hr}$. Plasma renin activity (PRA) was measured by the radioimmunoassay by Haber et al. ${ }^{8}$ )

\section{RESULTS}

\section{Effects of 20 minutes-standing on plasma DBH activity:}

The increase in plasma DBH activity of the hypertensives in the young (aged 20-39), the middle-aged (aged 40-59), and the old (aged above 60) was $19.3 \pm 10.1 \%, 8.4 \pm 3.5 \%$, and $6.8 \pm 5.0 \%$, respectively (Table $\mathrm{I}(1)$ ).

There were no significant differences among these age groups and no significant differences were also found in the basal plasma $\mathrm{DBH}$ activity of these groups.

The hypertensive patients were classified into the mild, moderate, and severe hypertensives by the hypertension severity index. The increase in plasma DBH activity by 20 minutes-standing was $10.4 \pm 6.1 \%, 4.2 \pm 4.5 \%$, and $3.1 \pm 5.1 \%$, in the mild, moderate, and severe hypertensives, respectively (Table $\mathrm{I}(2)$ ). The increase was more marked in the mild hypertensives than in the other groups though the difference was not significant.

Normal range of plasma renin activity was $2.20 \pm 1.32 \mathrm{ng} / \mathrm{ml} / \mathrm{hr}($ mean \pm 2SD), $1.68 \pm 1.4 \mathrm{ng} / \mathrm{ml} / \mathrm{hr}$, and $1.27 \pm 0.96 \mathrm{ng} / \mathrm{ml} / \mathrm{hr}$, in the age groups of 10 $29,30-59$, and above 60 years, respectively as previously reported. ${ }^{2}$ The hypertensive patients was classified by these age-matched normal range of PRA into high, normal and low renin groups. The increase in plasma DBH activity was significantly higher in the high renin hypertensives than in the 
Table I. Effects of 20 Minutes-Standing on Plasma DBH Activity

(1) in Relation to Age in Essential Hypertension

\begin{tabular}{l|c|r|r|r}
\hline \multirow{2}{*}{ Age (yrs) } & \multirow{2}{*}{$\begin{array}{c}\text { No. of } \\
\text { Cases }\end{array}$} & \multicolumn{2}{|c|}{ Plasma DBH Activity (I.U.) } & \multirow{2}{*}{$\begin{array}{c}\text { \% Increase in Plasma } \\
\text { DBH Activity (\%) }\end{array}$} \\
\cline { 3 - 5 } & 14 & $12.7 \pm 2.5$ & $13.6 \pm 2.0$ & $19.3 \pm 10.1$ \\
$20-39$ & 29 & $9.9 \pm 1.3$ & $10.5 \pm 1.2$ & $8.4 \pm 3.5$ \\
$40-59$ & 12 & $11.3 \pm 2.2$ & $12.1 \pm 2.4$ & $6.8 \pm 5.0$ \\
$60-$ & & &
\end{tabular}

(2) in Relation to Hypertension Severity Index

\begin{tabular}{c|c|c|c|c}
\hline \multirow{2}{*}{ Severity Index } & \multirow{2}{*}{$\begin{array}{c}\text { No. of } \\
\text { Cases }\end{array}$} & \multicolumn{2}{|c|}{ Plasma DBH Activity (I.U.) } & \% \\
\cline { 4 - 5 } & & Before & After & $\begin{array}{c}\text { Increase in Plasma } \\
\text { DBH Activity (\%) }\end{array}$ \\
\hline $1-6$ & 19 & $14.2 \pm 1.9$ & $15.1 \pm 1.8$ & $10.4 \pm 6.1$ \\
$7-10$ & 17 & $10.5 \pm 2.1$ & $10.6 \pm 1.8$ & $4.2 \pm 4.5$ \\
$11-$ & 12 & $9.7 \pm 2.2$ & $9.9 \pm 2.4$ & $3.1 \pm 5.1$ \\
\hline
\end{tabular}

(3) in High, Normal, and Low Renin Groups**

\begin{tabular}{l|c|c|c|c}
\hline $\begin{array}{c}\text { Plasma Renin } \\
\text { Group }\end{array}$ & $\begin{array}{c}\text { No. of } \\
\text { Cases }\end{array}$ & \multicolumn{2}{|c|}{ Plasma DBH Activity (I.U.) } & \multirow{2}{*}{$\begin{array}{c}\text { Increase in Plasma } \\
\text { DBH Activity (\%) }\end{array}$} \\
\cline { 3 - 5 } & 7 & Before & After & \\
\hline High Renin & 38 & $10.1 \pm 1.2$ & $10.8 \pm 1.1$ & $12.0 \pm 4.3$ \\
Normal Renin & 10 & $9.4 \pm 1.2$ & $10.0 \pm 1.3$ & $9.3 \pm 1.2-$ \\
Low Renin & & &
\end{tabular}

* $\mathrm{p}<0.05$

** There was no significant difference in hypertension severity index among 3 groups.

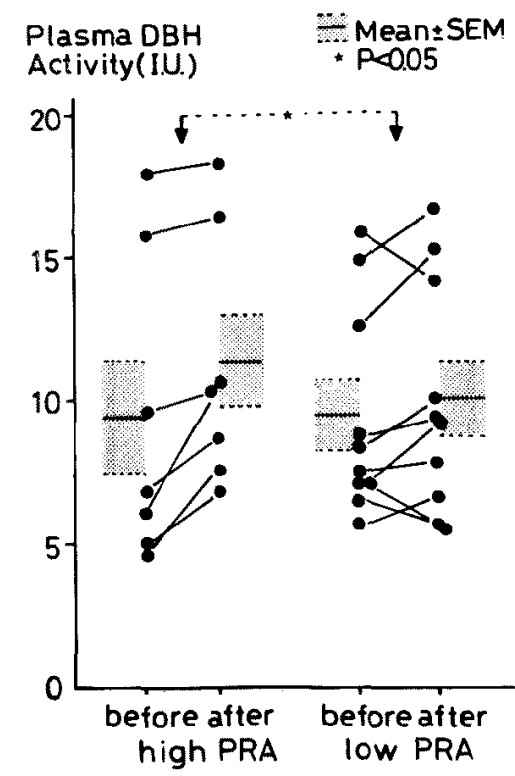

Fig. 1. Effects of 20 minutes-standing on plasma DBH activity in high and low renin groups. 


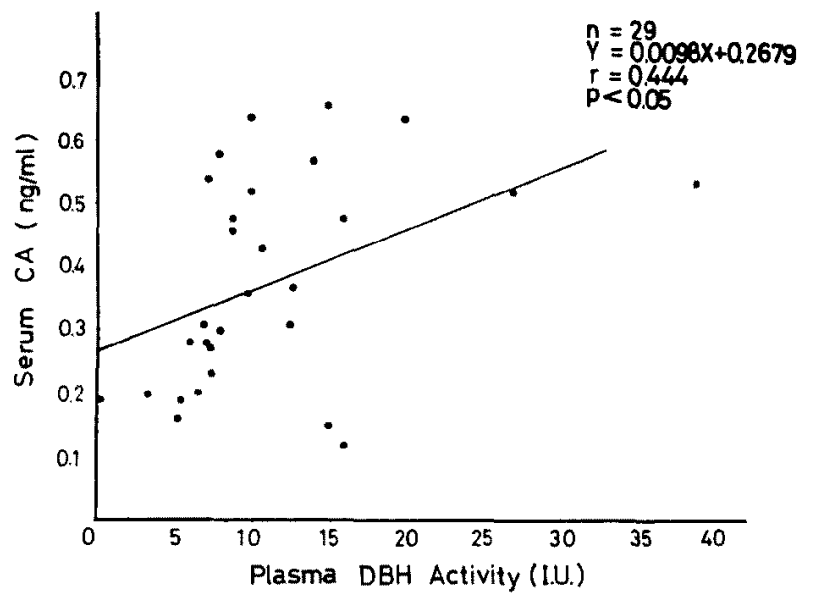

Fig. 2. Correlation between plasma DBH activity and serum catecholamine in the mild and moderate hypertension

low renin group $(\mathrm{p}<0.05)$ (Table $\mathrm{I}(3)$ and Fig. 1). There was no significant difference in the basal plasma DBH activity among these groups. Mean age in the high renin and the low renin groups was not significantly different. There was no significant correlation betwcen basal plasma DBH activity and PRA $(n=52, r=-0.11)$.

There was a significant correlation between plasma $\mathrm{DBH}$ activity and serum catecholamine in the mild and the moderate hypertensives $(r=0.444$, $\mathrm{p}<0.05$ ) (Fig. 2). The mean age of the subjects was $43.5 \pm 2.1$ years.

\section{Effects of treadmill exercise on plasma $D B H$ activity:}

Effects of treadmill exercise on plasma DBH activity were studied in 40 normotensives and 34 hypertensives in relation to age. The increase in plasma DBH activity in the normotensive subjects was $14.8 \pm 4.8 \%, 11.8 \pm$ $3.7 \%$, and $11.8 \pm 9.1 \%$, in the young, the middle-aged and the old, respectively (Table II (1)). The significant difference was not found in these age groups of normotensive subjects. The increase in plasma DBH activity in the hypertensive patients was $20.6 \pm 10.8 \%, 10.8 \pm 6.1 \%$, and $2.8 \pm 5.3 \%$, in the young, the middle-aged, and the old groups, respectively (Table II(1)). The increase was higher in the young group than the others, but the difference was not significant.

The increase in plasma DBH activity by treadmill exercise was $15.7 \pm$ $7.8 \%, 9.7 \pm 5.7 \%$, and $5.5 \pm 9.9 \%$, in the mild, moderate, and severe hypertensives, respectively (Table $\mathrm{II}(2)$ ). The increase was higher in the mild hypertensives than in the others, but the difference was not significant.

The increase in plasma DBH activity by treadmill exercise was more 
Table II. Effects of Treadmill Exercise on Plasma DBH Activity

(1) in Normotensive and Hypertensive Subjects

\begin{tabular}{|c|c|c|c|c|c|c|}
\hline \multirow{2}{*}{ Age (yrs) } & \multirow{2}{*}{$\begin{array}{l}\text { No. of } \\
\text { Cases }\end{array}$} & \multicolumn{2}{|c|}{ Plasma DBH Activity (I.U.) } & \multirow{2}{*}{$\begin{array}{l}\% \text { Increase in } \\
\text { Plasma DBH } \\
\text { Activity (\%) }\end{array}$} & \multirow{2}{*}{\multicolumn{2}{|c|}{$\begin{array}{c}\text { Change of } \\
\text { Heart Rate } \\
\text { per min. }\end{array}$}} \\
\hline & & Before & After & & & \\
\hline \multicolumn{7}{|l|}{ Normotensive } \\
\hline $20-39$ & 22 & $11.1 \pm 0.9$ & $12.5 \pm 0.9$ & $14.8 \pm 4.8$ & $67.4 \pm 4.8-$ & \\
\hline $40-59$ & 12 & $8.1 \pm 1.3$ & $8.7 \pm 1.2$ & $11.8 \pm 3.7$ & $58.6 \pm 7.4$ & \\
\hline $60-$ & 6 & $9.1 \pm 1.6$ & $9.7 \pm 1.3$ & $11.8 \pm 9.1$ & $36.4 \pm 7.8$ & \\
\hline \multicolumn{7}{|l|}{ Hypertensives } \\
\hline $20-39$ & 10 & $10.6 \pm 2.8$ & $12.2 \pm 3.4$ & $20.6 \pm 10.8$ & $20.6 \pm 11.9$ & \\
\hline $40-59$ & 15 & $8.1 \pm 1.3$ & $8.6 \pm 1.4$ & $10.8 \pm 6.1$ & $20.0 \pm 3.0$ & \\
\hline $60-$ & 9 & $10.7 \pm 1.5$ & $11.0 \pm 1.8$ & $2.8 \pm 5.3$ & $20.3 \pm 5.3$ & \\
\hline
\end{tabular}

The treadmill exercise was performed at the stage of III-IV (Kattus) in the normotensives, and at the stage $I$ in the hypertensive subjects.

(2) in Relation to Hypertension Severity Index

\begin{tabular}{c|r|r|r|r|r}
\hline \multirow{2}{*}{ Severity Index } & \multirow{2}{*}{$\begin{array}{c}\text { No. of } \\
\text { Cases }\end{array}$} & \multicolumn{2}{|c|}{ Plasma DBH Activity (I.U.) } & $\begin{array}{c}\text { \% Increase in } \\
\text { Plasma DBH } \\
\text { Activity (\%) }\end{array}$ & $\begin{array}{r}\text { Change of } \\
\text { Heart Rate } \\
\text { per min }\end{array}$ \\
\cline { 3 - 5 } $1-6$ & 14 & $11.7 \pm 1.7$ & $12.6 \pm 1.7$ & $15.7 \pm 7.8$ & $20.6 \pm 2.7$ \\
$7-10$ & 15 & $7.5 \pm 1.6$ & $8.3 \pm 2.1$ & $9.7 \pm 5.7$ & $16.8 \pm 1.2$ \\
$11-$ & 5 & $9.4 \pm 2.1$ & $9.9 \pm 2.6$ & $5.5 \pm 9.9$ & $16.8 \pm 5.0$ \\
\hline
\end{tabular}

The treadmill exercise was performed at the stage I (Kattus).

(3) in Relation to ECG Responses

\begin{tabular}{|c|c|c|c|c|c|c|c|}
\hline \multirow{2}{*}{\multicolumn{2}{|c|}{$\begin{array}{c}\text { ECG } \\
\text { Responses }\end{array}$}} & \multirow{2}{*}{$\begin{array}{l}\text { No. of } \\
\text { Cases }\end{array}$} & \multicolumn{2}{|c|}{ Plasma $\underset{\text { (I.U.) }}{\mathrm{DBH}}$ Activity } & \multirow{2}{*}{$\begin{array}{l}\% \text { Increase in } \\
\text { Plasma DBH } \\
\text { Activity }(\%)\end{array}$} & \multirow{2}{*}{$\begin{array}{l}\text { Mean } \\
\text { Age } \\
\text { (yrs) }\end{array}$} & \multirow{2}{*}{$\begin{array}{c}\text { Change of } \\
\text { Heart Rate } \\
\text { per min }\end{array}$} \\
\hline & & & Before & After & & & \\
\hline \multirow[t]{2}{*}{$\mathrm{EH}$} & Positive & 10 & $11.4 \pm 1.2$ & $13.4 \pm 1.2$ & $20.2 \pm 5.1-$ & $53.0 \pm 3.2$ & $59.7 \pm 2.5$ \\
\hline & Negative & 10 & $14.2 \pm 2.7$ & $16.0 \pm 3.6$ & $12.0 \pm 6.8$ & $44.9 \pm 5.1$ & $55.8 \pm 10.8$ \\
\hline \multirow[t]{2}{*}{ NT } & Positive & 12 & $7.8 \pm 0.9$ & $8.3 \pm 0.8$ & $10.0 \pm 5.7$ & $43.0 \pm 5.4$ & $58.4 \pm 5.9$ \\
\hline & Negative & 15 & $9.0 \pm 1.1$ & $9.6 \pm 1.1$ & $7.8 \pm 3.3-$ & $46.0 \pm 3.7$ & $56.5 \pm 8.4$ \\
\hline
\end{tabular}

The treadmill exercise was performed at the stage of III-IV (Kattus) in the normotensive and hypertensive subjects.

Values indicate Mean \pm SEM. $\quad * \mathrm{p}<0.05, \quad{ }^{* *} \mathrm{p}<0.01$

$\mathrm{EH}=$ essential hypertension, NT $=$ normotension.

marked in the hypertensives with positive ECG responses than in the normotensives with negative responses $(\mathrm{p}<0.05)$ (Table II $(3))$.

3. Effects of low sodium diet for 3 days and 2 hours-standing on plasma $D B H$ activity :

The responses of plasma $\mathrm{DBH}$ activity to low sodium diet for 3 days 
were observed in 34 patients with cssential hypertension. The increase in plasma DBH activity was $34.5 \pm 5.7 \%, 19.0 \pm 2.6 \%$, and $12.0 \pm 8.2 \%$, in the young, the middle-aged, and the old hypertensives, respectively (Table III(1)

Table III. Effects of Low Sodium Diet on Plasma DBH Activity

(1) in Relation to Age in Essential Hypertension

\begin{tabular}{|c|c|c|c|c|c|c|}
\hline \multirow{2}{*}{$\begin{array}{l}\text { Age } \\
(\text { yrs })\end{array}$} & \multirow{2}{*}{$\begin{array}{l}\text { No. of } \\
\text { Cases }\end{array}$} & \multicolumn{2}{|c|}{ Plasma $\underset{(\text { I.U. })}{\text { DBH Activity }}$} & \multirow{2}{*}{$\begin{array}{l}\% \text { Increase in } \\
\text { Plasma DBH } \\
\text { Activity }(\%)\end{array}$} & \multirow{2}{*}{$\begin{array}{l}\text { Severity } \\
\text { Index }\end{array}$} & \multirow{2}{*}{$\begin{array}{c}\text { Change of } \\
\text { Heart Rate } \\
\text { per min }\end{array}$} \\
\hline & & Before & After & & & \\
\hline $20-39$ & 8 & $10.0 \pm 1.9$ & $13.2 \pm 2.5$ & $34.5 \pm 5.7-=$ & $6.6 \pm 1.1$ & $3.2 \pm 2.4$ \\
\hline $40-59$ & 16 & $8.9 \pm 0.9$ & $9.9 \pm 1.3$ & $19.0 \pm 2.6{ }^{* *} *$ & $8.1 \pm 1.0$ & $2.1 \pm 3.3$ \\
\hline $60-$ & 10 & $10.5 \pm 1.6$ & $11.9 \pm 1.9$ & $12.0 \pm 8.2$ & $7.8 \pm 1.1$ & $4.0 \pm 2.6$ \\
\hline
\end{tabular}

(2) in Relation to Hypertension Severity Index

\begin{tabular}{|c|c|c|c|c|c|c|}
\hline \multirow{2}{*}{$\begin{array}{l}\text { Severity } \\
\text { Index }\end{array}$} & \multirow{2}{*}{$\begin{array}{l}\text { No. of } \\
\text { Cases }\end{array}$} & \multicolumn{2}{|c|}{$\begin{array}{l}\text { Plasma DBH Activity } \\
\text { (I.U.) }\end{array}$} & \multirow{2}{*}{$\begin{array}{l}\% \text { Increase in } \\
\text { Plasma DBH } \\
\text { Activity }(\%)\end{array}$} & \multirow{2}{*}{$\begin{array}{l}\text { Mean Age } \\
\text { (yrs) }\end{array}$} & \multirow{2}{*}{$\begin{array}{c}\text { Change of } \\
\text { Heart Rate } \\
\text { per min }\end{array}$} \\
\hline & & Before & After & & & \\
\hline $1-6$ & 11 & $10.1 \pm 1.5$ & $13.5 \pm 2.0$ & $35.2 \pm 6.5$ & $42.7 \pm 3.8$ & $4.5 \pm 3.0$ \\
\hline $7-10$ & 11 & $11.0 \pm 1.3$ & $12.6 \pm 1.5$ & $13.6 \pm 1.72^{*}$ & $47.6 \pm 3.2$ & $1.8 \pm 5.9$ \\
\hline $11-$ & 9 & $7.5 \pm 1.3$ & $8.3 \pm 1.6$ & $10.1 \pm 4.5$ & $58.0 \pm 4.0-$ & $1.3 \pm 2.7$ \\
\hline
\end{tabular}

Values indicate Mean \pm SEM. $\quad * \mathrm{p}<0.05, \quad * * \mathrm{p}<0.01$.

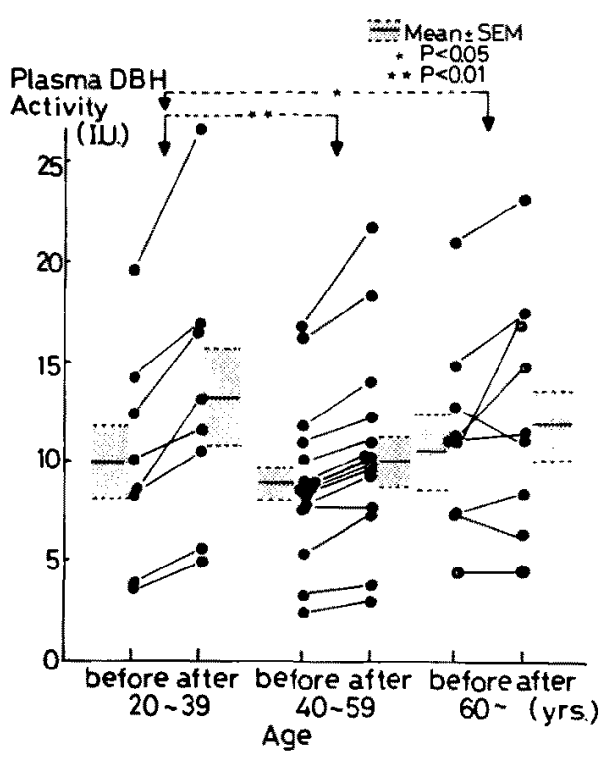

(A)

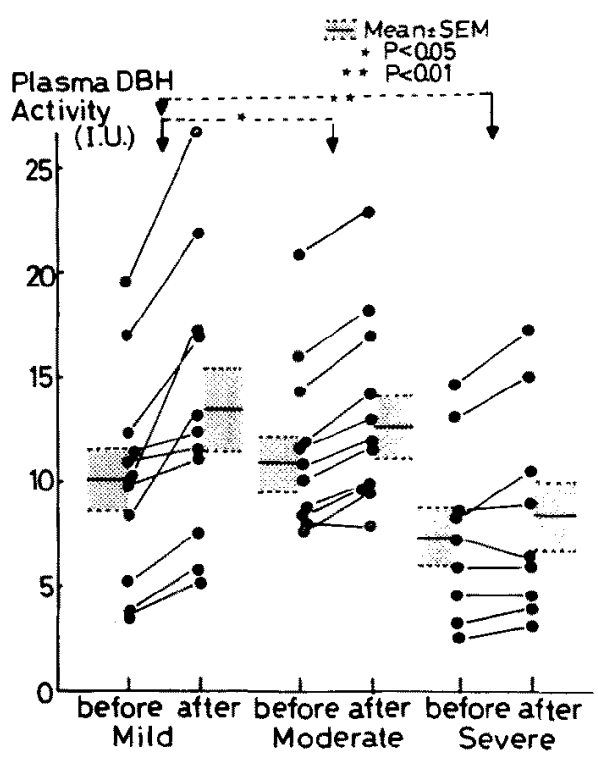

(B)

Fig. 3 (A) Effects of low sodium diet for 3 days on plasma DBH activity in relation to age in essential hypertension.

(B) Effects of low sodium diet for 3 days on plasma DBH activity in relation to hypertension severity index. 
and Fig. 3A. The responses in the young hypertensives were significantly higher than those in the middle aged $(\mathrm{p}<0.01)$ and the old $(\mathrm{p}<0.05)$, respectively.

The increase in plasma DBH activity was $35.2 \pm 6.5 \%, 13.6 \pm 1.7 \%$, and $10.1 \pm 4.5 \%$ in the mild, moderate, and severe hypertensives, respectively (Table III(2) and Fig. 3B). The responses were also significantly higher in the mild hypertensives than those in the moderate $(p<0.05)$ and the severe hypertensives $(\mathrm{p}<0.01)$, respectively. The mean age in these groups was $42.7 \pm 3.8 \mathrm{yrs}, 47.6 \pm 3.2 \mathrm{yrs}$, and $58.0 \pm 4.0 \mathrm{yrs}$, respectively. The age in the mild hypertensives was significantly younger than in the severe hypertensives $(\mathrm{p}<0.05)$.

Further, the increase in plasma DBH activity by 2 hours-standing after low sodium diet was $39.1 \pm 9.8 \%, 20.0 \pm 3.5 \%$, and $19.7 \pm 6.2 \%$, in the young, the middle-aged, and the old hypertensives, respectively (Table IV(1)). The responses were significantly higher in the young group than in the middle-

Table IV. Effects of Low Sodium Diet and 2 Hours-Standing on Plasma DBH Activity

(1) in Relation to Age in Essential Hypertension

\begin{tabular}{|c|c|c|c|c|c|}
\hline \multirow{2}{*}{ Age (yrs) } & \multirow{2}{*}{$\begin{array}{l}\text { No. of } \\
\text { Cases }\end{array}$} & \multicolumn{2}{|c|}{ Plasma DBH Activity (I.U.) } & \multirow{2}{*}{$\begin{array}{l}\% \text { Increase in } \\
\text { Plasma DBH } \\
\text { Activity }(\%)\end{array}$} & \multirow{2}{*}{$\begin{array}{l}\text { Severity } \\
\text { Index }\end{array}$} \\
\hline & & Before & After & & \\
\hline $20-39$ & 7 & $9.5 \pm 2.2$ & $12.4 \pm 2.5$ & $39.1 \pm 9.8-$ & $5.9 \pm 0.7$ \\
\hline $40-59$ & 12 & $9.8+1.1$ & $11.7 \pm 1.5$ & $20.0 \pm 3.5$ & $7.5 \pm 0.9$ \\
\hline $60-$ & 8 & $10.9 \pm 1.8$ & $12.7 \pm 1.9$ & $19.7 \pm 6.2$ & $8.1 \pm 1.1$ \\
\hline
\end{tabular}

(2) in Relation to Hypertension Severity Index

\begin{tabular}{c|c|c|c|c|c}
\hline $\begin{array}{c}\text { Severity } \\
\text { Index }\end{array}$ & $\begin{array}{c}\text { No. of } \\
\text { Cases }\end{array}$ & \multicolumn{2}{|c|}{ Plasma DBH Activity (I.U.) } & $\begin{array}{c}\text { \% Increase in } \\
\text { Plasma DBH } \\
\text { Activity (\%) }\end{array}$ & $\begin{array}{c}\text { Mean Age } \\
\text { (yrs) }\end{array}$ \\
\hline $1-6$ & 12 & $10.0 \pm 1.4$ & $13.2 \pm 1.7$ & $36.7 \pm 7.1-$ & $45.4 \pm 3.7$ \\
$7-10$ & 11 & $10.9 \pm 1.4$ & $12.1 \pm 1.4$ & $12.5 \pm 3.7-$ & $48.2 \pm 3.5$ \\
$11-$ & 6 & $7.1 \pm 1.5$ & $9.0 \pm 2.3$ & $25.0 \pm 6.1$ & $55.2 \pm 4.2$
\end{tabular}

Values indicate Mean \pm SEM. $\quad * \mathrm{p}<0.05, \quad * * \mathrm{p}<0.01$.

Table V. Effects of Low Sodium Diet on Plasma

\begin{tabular}{|c|c|c|c|}
\hline \multirow{2}{*}{$\begin{array}{c}\text { Mean Blood Pressure } \\
\text { Fall }\end{array}$} & \multirow{2}{*}{$\begin{array}{l}\text { No. of } \\
\text { Cases }\end{array}$} & \multicolumn{2}{|c|}{ Plasma DBH Activity (I.U.) } \\
\hline & & Before & After \\
\hline$\geqq 10 \mathrm{mmHg}$ & 12 & $9.3 \pm 1.0$ & $11.6 \pm 1.4$ \\
\hline$<10 \mathrm{mmHg}$ & 13 & $9.0 \pm 1.1$ & $9.8 \pm 1.4$ \\
\hline
\end{tabular}

Values indicate Mean \pm SED. $\quad * \mathrm{p}<0.05, \quad * * * \mathrm{p}<0.001$. 
aged group $(\mathrm{p}<0.05)$

The increase in plasma $\mathrm{DBH}$ activity was $36.7 \pm 7.1 \%, 12.5 \pm 3.7 \%$, and $25.0 \pm 6.1 \%$, in the mild, moderate, and severe hypertensives, respectively (Table IV(2)). The responses were also significantly higher in the mild hypertensives than in the moderate group $(\mathrm{p}<0.01)$.

The increase in plasma DBH activity was compared between the groups with and without significant mean blood pressure fall of more than $10 \mathrm{mmHg}$ by sodium restriction. The increase in plasma $\mathrm{DBH}$ activity was significantly higher in the former than that in the latter group $(p<0.05)$ (Table $V$ and Fig. 4). Hypertension severity index was significantly lower in the former

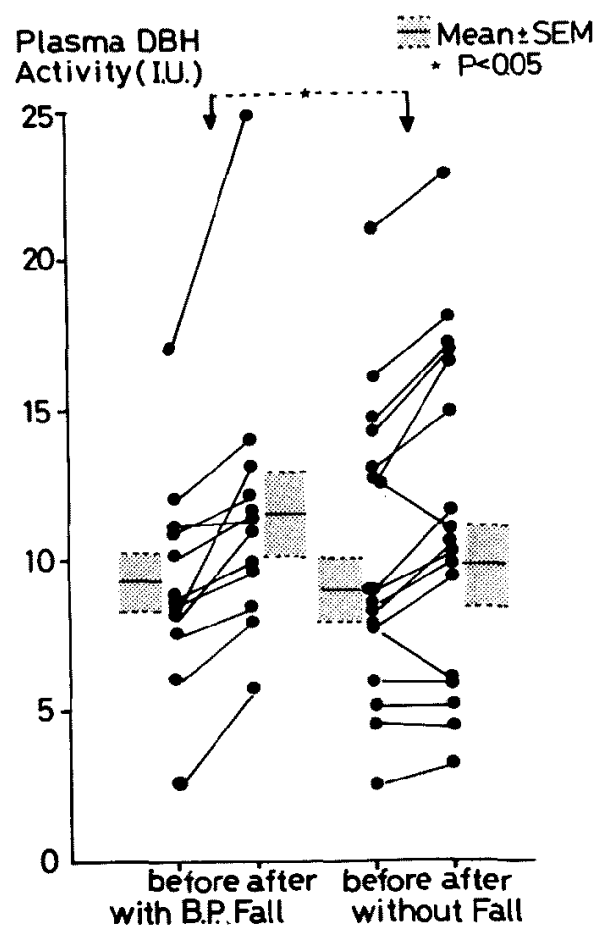

Fig. 4. Effects of low sodium diet for 3 days on plasma DBH activity in relation to blood pressure fall.

DBH Activity in Relation to Blood Pressure Fall

\begin{tabular}{c|c|c|c}
\hline $\begin{array}{c}\% \text { Increase in Plasma } \\
\text { DBH Activity (\%) }\end{array}$ & $\begin{array}{c}\% \text { Increase in Plasma } \\
\text { Renin Activity (\%) }\end{array}$ & $\begin{array}{c}\text { Mean Age } \\
(\mathrm{yrs})\end{array}$ & Severity Index \\
\hline $32.8 \pm 10.3-$ & $175.1 \pm 31.0-$ & $47.6 \pm 3.0$ & $6.3 \pm 0.6-{ }^{* * *}$ \\
$9.3 \pm 4.1-^{*}$ & $33.6 \pm 6.0-$ & $49.5 \pm 3.0$ & $8.7 \pm 0.7-^{*}$
\end{tabular}


than in the latter group $(\mathrm{p}<0.05)$. The increase in PRA was also significantly higher in the former than in the latter group $(p<0.001)$ but significant difference was not found in the basal PRA between these groups. The mean age was not significantly different between them.

\section{Discussion}

It has been suggested that the sympathetic nerve system might play a role in the production and the maintenance of hypertension. Generally, various exercises cause the sympathetic nerve stimulation.

The plasma $\mathrm{DBH}$ activity was reported to be increased significantly in cold pressor test, ${ }^{10)}$ after standing ${ }^{11)}$ or after submaximal work load in man, ${ }^{12}$ ) and in rats subjected to the immobilization stress, ${ }^{13)}$ and swim stress. ${ }^{14}$ )

The increase in plasma DBH activity by low sodium diet for 3 days was significantly higher in the young hypertensives than in the middle-aged and the old. The increase in plasma DBH activity was also significantly higher in the mild hypertensives than in the moderate and the severe hypertensives.

Similar results were found by low sodium diet for 3 days and 2 hoursstanding. The responses were significantly higher in the mild than in the moderate hypertensives. These results suggest that the sympathetic nerve system might play a role in the early stage of essential hypertension. The increase in plasma DBH activity in the hypertensives with the mean blood pressure fall of more than $10 \mathrm{mmHg}$ by salt restriction was significantly higher than in those without significant blood pressure fall. Many mild hypertensives were included in the former group, while the severe hypertensives were included in the latter. These results also suggest the participation of the sympathetic nerve system in the early stage of hypertension.

An interaction of the sympathetic nerve system with renin-angiotensin system has been suggested to play a role in the pathogenesis of hypertension. The renal sympathetic nerve activity affects renin release and renin-angiotensin system also affects sympatho-adrenal system. ${ }^{15}$ )

It was reported that $70 \%$ of hypertensives with high renin showed increased serum catecholamine levels. ${ }^{16)}$ In our study, the increase in plasma DBH activity by 20 minutes-standing was significantly higher in the high renin hypertensives than in the low renin group. The sympathetic hyperactivity might be partly induced by renin-angiotensin system in the high renin hypertensives.

There has been some discrepancy about serum catecholamine levels in essential hypertension. ${ }^{17-20}$ Geffen et $\mathrm{al}^{21)}$ reported that plasma catecholamine was parallel to plasma DBH amounts measured by radioimmunoassay. 
Schanberg et a ${ }^{22}$ reported that there was high correlation between urinary catecholamine and plasma DBH activity. In our study, the significant correlation was found between plasma DBH activity and serum catecholamine levels in the mild and the moderate hypertension.

Plasma DBH activity is a useful indicator of the sympathetic nerve activity. As there are some individual variations in plasma DBH activity, it is more suitable to examine the responses of plasma DBH activity to the stimuli than the basal activity, as an indicator of the sympathetic nerve activity.

These results suggest that the sympathetic nerve activity might participate in the development of hypertension, especially in the early stage of hypertension.

\section{REFERENGES}

1. Kuchii M, Iseki F, Miyamoto Y, Nishio I, Masuyama Y: Age-related changes in plasma dopamine $\beta$-hydroxylase and renin activities. The XIth International Congress of Gerontology, Tokyo, Aug 25th, 1978

2. Iseki F, Kuchii M, Nishio I, Masuyama $Y$ : The evaluation of plasma dopamine $\beta$-hydroxylase activity in essential and secondary hypertension. Jap Heart J 20: 307, 1979

3. Hypertension Research Committee of Tokyo University: The criteria for hypertension of severity determination. Modern Medicine 22: 2027, 1967

4. Kattus AA, Jargensen CR, Worden RE, Alvaro AB: ST-segment depression with nearmaximal exercise in detection of preclinical coronary heart disease. Circulation 44: 585, 1971

5. Robinson S: Experimental studies of physical fitness in relation to age. Arbeitphysiologie 10: 251,1938

6. Nagatsu $T$, Udenfriend S: Photometric assay of dopamine- $\beta$-hydroxylase activity in human blood. Clin Chem 18: 980,1972

7. De Champlain J, Farley L, Cousineau D, Van Ameringen MR: Circulating catecholamine levels in human and experimental hypertension. Circulat Res 38:109, 1976

8. Haber E, Kverner T, Page LB, Kliman B, Purnode A: Application for Angiotensin I to the physiologic measurements of plasma renin activity in normal human subjects. J Clin Endocrinol 29: 1349, 1969

9. Miyamoto Y, Ueno Y, Kuchii M, Otani H, Tamaki T, Nishio I, Masuyama Y: Plasma renin activity in essential hypertension with respect to aging and hypertension severity and stimulation test. J Jap Soc Int Med 67: 1224, 1978

10. Wooten GF, Cardon PV: Plasma dopamine $\beta$-hydroxylase activity. Elevation in man during cold pressor test and exercise. Arch Neurol 28: 103, 1973

11. Sellers EM, Cooper SD, Roy M: Fluctuation in human serum dopamine $\beta$-hydroxylase. Pharmacologist 16: 235, 1974

12. Planz G, Palm D: Acute enhancement of dopamine- $\beta$-hydroxylase activity in human plasma after maximam work load. Europ J Cli Pharmacol 5: 255, 1973

13. Weinshilboum RM, Kventnansky R, Kopin JJ: Elevation of serum dopamine $\beta$-hydroxylase activity with forced immobilization. Nature New Biol 230: 287, 1971

14. Roffman M, Freedman LS, Goldstein $M$ : The effect of acute and chronic swim stress on dopamine- $\beta$-hydroxylase activity. Life Sci 12: 369, 1973

15. DeQuattro L, Miura Y: Neurogenic factors in human hypertension. Mechanism and why? Am J Med 55: 362, 1973

16. DeQuattro V, Campese V, Miura Y, Meijer D: Increased plasma catecholamines in high 
renin hypertension. Am J Cardiol 38: 801, 1976

17. Sever PS, Birch M, Osikowska B, Tunbridge RDG: Plasma noradrenaline in essential hypertension. Lancet 1: 1078, 1977

18. Campese V, Myers MR, DeQuattro V: Plasma catecholamines and neurogenic hypertension. New Engl J Med 297: 53, 1977

19. De Champlain J, Cousineau D: Lack of correlation between age and circulating catecholamines in hypertensive patients. New Engl J Med 297: 672, 1977

20. Lake CR, Ziegler MG, Coleman MD, Kopin IJ: Age-adjusted plasma norepinephrine levels are similar in normotensive and hypertensive subjects. New Engl J Med 296: 208, 1977

21. Geffen LB, Rush RA, Jouis WJ, Doyle AE: Plasma dopamine- $\beta$-hydroxylase and noradrenaline amounts in essential hypertension. Clin Sci 46: 617, 1974

22. Schanberg SM, Stone RA, Kirshner N, Gunnells JC, Robinson RR: Plasma dopamine $\beta$-hydroxylase. A possible aid in the study and evaluation of hypertension. Science 183: 523,1974 